\title{
A gastrointestinalis daganatok és szív-ér rendszeri betegségek standardizált halálozási arányszámai Magyarország négy borvidékén és egy nem borvidéken 2000-2010 között
}

\author{
Nagy János ${ }^{1}$ - Sipka Sándor dr. ${ }^{2}$ - Kocsis Judit dr. ${ }^{1}$ - Horváth Zsolt dr. ${ }^{1}$ \\ Debreceni Egyetem, Általános Orvostudományi Kar, \\ ${ }^{1}$ Onkológiai Intézet, ${ }^{2}$ Klinikai Immunológiai Tanszék, Debrecen
}

\begin{abstract}
Bevezetés: Az étkezési szokásoknak meghatározó szerepe van a gastrointestinalis daganat és szív-ér rendszer eredetú halálozásokban.

Célkitüzés: Annak vizsgálata, hogy a borfogyasztásnak lehet-e szerepe a két haláltípus kialakulásában Magyarországon.

Módszer: A szerzók 206159 személy adataiból hasonlították össze a gastrointestinalis daganatok és szív-ér rendszeri megbetegedések miatt 2000-2010 között meghalt személyek standardizált elhalálozási arányszámait négy történelmi borvidéken: Tokaj (fehérbor), Eger (vörösbor), Balaton (fehérbor), Szekszárd/Villány (vörösbor) vidékén és a nem borvidék Hódmezővásárhelyen.

Eredmények: A Tokaj vidéken volt szignifikánsan a legkisebb a daganatok száma (664), viszont a szív-ér rendszeri betegségek miatti halálozás itt volt a legnagyobb (5955). Ezzel szemben a szív-ér rendszeri betegségek száma Szekszárd-Villány területén (3907) a legkevesebb, míg a daganatoké itt (831) és Eger vidékén (934) a legtöbb.

Következtetések: Igazolódott a vörösbor ismert védőhatása a szív-ér rendszeri halálozásokban. A gastrointestinalis daganatos elhalálozás meglepően alacsony előfordulása a Tokaj vidéken - az ivóvíz magasabb szelénszintje mellett az itteni fehérborok eddig nem ismert sajátosságaira utal.

Orv Hetil. 2017; 158(25): 992-998.
\end{abstract}

Kulcsszavak: bor, gastrointestinalis daganat, mortalitás, szív-ér rendszeri betegség, Tokaj

The standardized mortality numbers of patients with gastrointestinal tumors and cardiovascular diseases in four wine regions and in one not-wine region of Hungary between 2000-2010

\footnotetext{
Introduction: Eating habits act on mortalities from gastrointestinal tumors and cardiovascular diseases. Aim: To investigate the role of wine drinking on these mortalities in Hungary.

Method: The standardized mortality data of people from 206,159 subjects died of gastrointestinal tumors and cardiovascular diseases between 2000-2010 were compared in four wine regions: Tokaj (white), Eger (red), Balaton (white), Szekszárd/Villány (red) and in Hódmezővásárhely (not-wine region).

Results: The significantly smallest number of tumors (664) occurred in Tokaj, but the cardiovascular mortality here was the highest (5955). On the other hand, the fewest cardiovascular mortality occurred in Szekszárd/Villány (3907), but showing here (831) and in Eger (934) the highest values of tumor death.

Conclusions: The protective effect of red wine on cardiovascular mortality was verified. Surprisingly, the low value of gastrointestinal mortality in "Tokaj" - besides the higher level of selenium in tap water - shows some hidden features of these white wines.
} 
Keywords: cardiovascular diseases, gastro-intestinal tumors, mortality, Tokaj, wine

Nagy J, Sipka S, Kocsis J, Horváth Zs. [The standardized mortality numbers of patients with gastrointestinal tumors and cardiovascular diseases in four wine regions and in one not-wine region of Hungary between 2000-2010]. Orv Hetil. 2017; 158(25): 992-998.

(Beérkezett: 2017. április 10; elfogadva: 2017. május 4.)

\section{Rövidítések}

$\mathrm{DI}=$ deprivációs index; GI = gastrointestinalis; SHA = standardizált halálozási arányszám; SZÉM = szív-ér rendszeri megbetegedés; TGS = társadalmi-gazdasági státusz

A szív-ér rendszeri megbetegedések (SZÉM) és a rosszindulatú daganatok jelentik a két vezető halálokot a fejlett világban. Örvendetes, hogy az utóbbi harminc évben jelentős csökkenés történt a halálozások számában, fóként a SZÉM okozta halálozásokban mind Európában, mind Magyarországon. A daganateredetű mortalitás aránya azonban - egy-két ország kivételével - növekszik, és nálunk nagyobb mértékben, mint Európában [1]. Bár komoly eredmény, hogy a szív-ér rendszeri betegségek korai felismerése nálunk is sokat javult, de sok daganat már csak késői, áttétes formában kerül kivizsgálásra a megfelelő monitorrendszer hiányában [2].

Ebben a nagyon összetett jelenségben az orvostudomány hatalmas fejlődése mellett számos új, környezeti és életmódbeli változás hatása is érvényre jut, amelyekből a táplálkozás kiemelt jelentőségü. Nemzetközi és hazai közlemények mutatják, hogy a vörösborfogyasztás és a zöldségben, gyümölcsben gazdag „mediterrán diéta” védőhatású a SZÉM-ben $[3,4]$. A kismértékű alkoholfogyasztás pedig italtípustól függetlenül segíti a keringési rendszer múködését [5]. Ugyanakkor magyarázatra vár a daganatos incidencia növekedése, amiben - sok egyéb mellett - egyik tényező lehet a vörös hús (sertés, szarvasmarha) megnőtt fogyasztásának gastrointestinalis (GI) daganatképzést fokozó hatása is [6].

Ezek alapján ebben a munkában vizsgálni kívántuk Magyarország négy, nagy hagyományú történelmi borvidékén és egy nem borvidéknek számító területén, összesen 206159 személy adataiból a GI-daganatokban és SZÉM-ben 2000-2010 között elhaltak számát, megadva a 100000 fóre számított, standardizált mortalitási arányszám (SHA) értékeit [7]. Az összehasonlíthatóság érdekében a közel azonos, az országos átlag feletti életszínvonalon, de különböző területeken élő, kisvárosi lakosságot vizsgáltuk. A területekre jellemző borok különbségei mellett elemeztük az egy lakosra jutó éves vörös (tőke-) hús fogyasztását, továbbá a talaj és a vezetékes ivóvíz ásványianyag-tartalmát [6-9], mint olyan potenciális faktorokat, amelyek a SZÉM és GI-daganatos mortalitást makroszinten befolyásolhatják.

\section{A vizsgált területek és domináns bortípusaik}

Magyarország ismert történelmi bortermelő területei közül az alábbiakat vizsgáltuk, feltüntetve ezeken belül azokat a településeket, vidékeket, amelyek mortalitási adatait elemeztük, valamint az ezekre a területekre dominánsan jellemző borfajtákat:

- Tokaj: Tokaj, Sárospatak, Sátoraljaújhely, dominánsan fehérbor;

- Eger: Eger, Noszvaj, dominánsan vörösbor;

- Balaton: Badacsonytomaj, Badacsonytördemic, Balatonboglár, Balatonfüred, Balatonlelle, Csopak, Dörgicse, dominánsan fehérbor;

- Szekszárd/Villány: dominánsan vörösbor;

- Hódmezôpásárbely: nem történelmi borvidék, kontrollként szerepel.

Ezeknek a helységeknek a kiválasztásában fontos szempont volt, hogy a jellegzetes, tradicionális borkultúrájuk mellett az itt élő emberek megközelítően azonos, egybevethető deprivációs indexet (DI-t), azaz az országos átlagot meghaladó társadalmi-gazdasági státuszt (TGS-t) képviselnek, továbbá az éves sertés-szarvasmarha (tőke-) hús fogyasztásukban sincs jelentős különbség. Lényeges az is, hogy legalább 30000 személy adatait lehetett vizsgálni egy-egy területen 11 éven keresztül. A megadott, pontos lakosságszám és depriváció a 20102011. évi, a húsfogyasztás a 2006-2007-es (gazdasági válság előtti) állapotot mutatja. Ezeket az adatokat az 1. táblázat tartalmazza.

\begin{tabular}{l|l} 
1. táblázat & $\begin{array}{l}\text { A lakosságszám, deprivációs index és a sertés-marha tókehús fo- } \\
\text { gyasztására vonatkozó adatok az egyes vidékeken 2006-2011 } \\
\text { között }\end{array}$
\end{tabular}

\begin{tabular}{|c|c|c|c|c|c|}
\hline Paraméterek & Tokaj & Eger & Balaton & $\begin{array}{l}\text { Szekszárd/ } \\
\text { Villány }\end{array}$ & $\begin{array}{l}\text { Hódmező- } \\
\text { vásárhely }\end{array}$ \\
\hline $\begin{array}{l}\text { Lakosságszám } \\
(2010)\end{array}$ & 33917 & 56981 & 30833 & 37268 & 47160 \\
\hline $\begin{array}{l}\text { Deprivációs } \\
\text { index (2011) }\end{array}$ & $-0,36$ & $-1,1$ & $-1,22$ & $-1,17$ & $-0,43$ \\
\hline 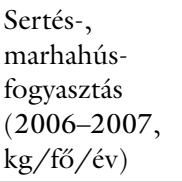 & 16,15 & 16,15 & 18,65 & 16,95 & 24,35 \\
\hline
\end{tabular}




\section{Mérési módszerek}

\section{Standardizált halálozási arányszám (SHA)}

Vizsgálatunkban a 2000-2010 közötti 11 éves intervallumban Magyarországon meghalt személyek adatait használtuk fel, amelyeket településszinten a Közigazgatási és Elektronikus Közszolgáltatások Központi Hivatalától és a Központi Statisztikai Hivataltól (KSH) kaptunk meg nemenkénti és diagnózis szerinti bontásban. (Ezeket az adatokat a Debreceni Egyetem Általános Orvosi Kara nem nyilvános közlés formájában kapja - a többi orvoskarhoz hasonlóan - rendszeresen és folyamatosan.) A rosszindulatú GI-daganatok, valamint SZÉM-ek diagnózisainak kiválasztása a Betegségek Nemzetközi Osztályozása (BNO) intervallumai alapján történt, amelyek a következők: emésztőszervi rosszindulatú daganatok: C15-C26; szív-ér betegségek: I01, I20-I99 (a hypertonia és az idült reumás szívbetegségek kivételével minden keringési betegség) [10]. Területenként vagy településenként 100000 före vetített standardizált halálozási arányszámot (SHA) képeztünk mindkét betegségcsoportban. Az SHA azt a halandóságot mutatja 100000 fóre vonatkoztatva, amely a vizsgált térségben akkor lenne megfigyelhető, ha a népességének összetétele ugyanolyan lenne, mint a standardnak választott európai népességé.

\section{Deprivációs index}

A települések, illetve területek adatainak összehasonlításakor szükségesnek tartottuk figyelembe venni a települések közötti társadalmi-gazdasági egyenlőtlenségeket, amelyek közismerten jelentős hatást gyakorolhatnak a különböző földrajzi helyen élők egészségi állapotára, halálozási mutatóira. Ezért használtuk az egyes területek társadalmi-gazdasági státuszának (TGS) jellemzésére és összehasonlítására a Juhász és mtsai [11] javaslata alapján kiszámolható „deprivációs indexet” (DI), ami az elmaradottságot, a „deprivációt” méri. A negatív előjel az átlagnál jobb életkörülményt jelzi, ami annál jobb, minél nagyobb abszolút számot mutat. A pozitív előjelű magas szám nagy elmaradottságot jelent. A számításhoz hat, a KSH-tól beszerezhető TGS-indikátort használtunk fel. Ezek:

- az állandó lakosság körének egyévi bruttó, egy főre eső jövedelme (a személyi jövedelemadó alapja) ezer forintban;

- a legalább 15 éves populációban az általános iskolát nem végzettek részaránya százalékban;

- a munkanélküliek részaránya a 15-74 éves népességben;

- az egyszülős, gyereket nevelő családok részaránya a családok között;

- lakószobánkénti személyek száma;

- száz lakosra jutó személygépkocsik száma.
A fenti jelzőszámokból fókomponens-elemzéssel határoztuk meg a deprivációs indexet. A települési indexekből népességszámmal súlyozott átlagként határoztuk meg az egyes területek mutatószámait.

Az egy fớre jutó egyéves vörös (sertés-marha tőke) hús fogyasztás adatainak forrása: Dr. Zádori László, az Országos Vágóállat és Hús Terméktanács fơtitkáraként kérte meg a KSH-tól az ország hét régiójában az egy főre jutó, vágóállat-eredetű, „tőkehús” jellegü sertés- és marhahús-fogyasztási adatokat kg/év/fó bontásban, amely értékek azonban nem tartalmazzák a „füstölt” termékek (például kolbász, szalámi, sonka stb.) adatait. A vizsgált területekkel összefüggésben az azokat tartalmazó KSHrégióknak megfelelő, 2006-2007. évi húsfogyasztási értékeket mutatjuk be.

A talaj ásványianyag-tartalmára vonatkozó adatok forrása: Gulyás Edit és Szentes Dóra, a Nemzeti Élelmiszerlánc-biztonsági Hivatal (NÉBIH) szakértői. A 4. táblázatban a különböző területek 30-50 hatósági helyszínén 2005-2010 között vett mintáinak átlagait adtuk meg, amelyeket a két szakértő által megküldött, ellenőrzött és jóváhagyott, több száz értékbőol számoltunk ki.

A vezetékes ivóviz áspányianyag-tartalmára vonatkozó adatok forrása: Dr. Vargha Márta, Sebestyén Ágnes, Dr. Pándics Tamás és Dr. Dura Gyula, az OKI/ÁNTSZ szakértői. Az 5. táblázatban az egyes területek 30-50 hatósági helyszínén 2005-2010 között vett mintáinak átlagát adtuk meg, amelyeket a szakértők által megküldött, ellenőrzött és jóváhagyott, több száz értékből számoltunk ki.

Statisztikai értékelés: Az évente kiszámított SHA-értékeket területenként összesítettük a vizsgált 11 évre, majd az egyes vidékek népességszáma alapján arányosítással meghatároztuk az elhalálozott személyek számát. A kapott adatok alapján előbb együttesen az öt területre, majd területpáronként Pearson-féle $\chi^{2}$-próbát végeztünk. A p <0,05 értéket tartottuk szignifikáns különbségnek, azonban az együttes próba mindkét betegségcsoport esetén $\mathrm{p}<0,005$ szinten is szignifikáns volt. A páronkénti vizsgálat $\mathrm{p}$-értékeit, illetve a relatív halálozási kockázat mutatóit a 3/A és 3/B táblázat mutatja. A számításhoz a StataCorp Stata 10.1 programját használtuk.

\section{Eredmények}

\section{A GI-daganatok és a SZÉM standardizált elhalálozási arányszámai 2000-2010 között}

A Tokaj vidéken volt a legkisebb (664) a GI-daganatokból származó standardizált elhalálozási arányszám (SHA), és Eger (934), továbbá Szekszárd/Villány (831) területén a legnagyobb. A Balatonnál (824) és Hódmezővásárhelyen (821) a két szélső érték közötti eredmények mutatkoztak. Az országos érték: 887, ehhez viszonyítva a Tokaj (664) és Eger (934) értékei jelentős, ellentétes irányú, szélső eltéréseket mutatnak. A SZÉMadatokban a szélső értékek fordított, „reciprok” megjelenését kaptuk. A legkisebb mortalitás a Szekszárd/ 
2. táblázat | A GI-daganatok és a SZÉM standardizált halálozási arányszámai 2000-2010 között vidékenként

\begin{tabular}{llllll}
\hline Halálokok & Tokaj & Eger & Balaton & Szekszárd/Villány & Hódmezővásárhely \\
\hline GI-daganatok/100 000 fö (orsz: 887/81) & $664\left(60^{*}\right)$ & $934\left(85^{*}\right)$ & $824\left(75^{*}\right)$ & $831\left(76^{*}\right)$ & $821\left(75^{*}\right)$ \\
SZÉM/100 000 fó (orsz: 4800/436) & $5955\left(541^{*}\right)$ & $4191\left(381^{*}\right)$ & $4034\left(367^{*}\right)$ & $3907\left(355^{*}\right)$ & $5178\left(471^{*}\right)$ \\
\hline
\end{tabular}

*Zárójelben az éves átlag.

orsz: országos érték/éves érték

3. táblázat | A GI-daganatok és a SZÉM lakosságszámra vonatkoztatott relatív halálozási kockázata a különböző vidékeken 2000-2010 között növekvő sorrendben

A) Gastrointestinalis daganatok

\begin{tabular}{|c|c|c|c|c|c|}
\hline Régiók & Tokaj & Hódmezôvásárhely & Balaton & Szekszárd/Villány & Eger \\
\hline Tokaj & 1 & $1,24^{*}(0,0107)$ & $1,24^{*}(0,0174)$ & $1,25^{* *}(0,0094)$ & 1,41 **** $(0,0000)$ \\
\hline Eger & $0,71 * * * *(0,0000)$ & $0,88(0,0522)$ & $0,88(0,0990)$ & $0,89(0,1043)$ & 1 \\
\hline Balaton & $0,81 *(0,0174)$ & $1,0(0,9616)$ & 1 & $1,01(0,9085)$ & $1,13(0,0990)$ \\
\hline Szekszárd/Villány & $0,80 * *(0,0094)$ & $0,99(0,8582)$ & $0,99(0,9085)$ & 1 & $1,12(0,1043)$ \\
\hline Hódmezővásárhely & $0,81 *(0,0107)$ & 1 & $1,0(0,9616)$ & $1,01(0,8582)$ & $1,14(0,0522)$ \\
\hline
\end{tabular}

B) Szív- és érrendszeri megbetegedések

\begin{tabular}{|c|c|c|c|c|c|}
\hline Régiók & Szekszárd/Villány & Balaton & Eger & Hódmezővásárhely & Tokaj \\
\hline Tokaj & $0,66^{* * * *}(0,0000)$ & $0,68 * * * *(0,0000)$ & $0,70 * * * *(0,0000)$ & $0,87^{*}(0,0000)$ & 1 \\
\hline Eger & $0,93 *(0,0311)$ & $0,96(0,2671)$ & 1 & $1,24 * * * *(0,0000)$ & $1,42 *(0,0000)$ \\
\hline Balaton & $0,97(0,3949)$ & 1 & $1,04(0,2671)$ & $1,28 * * * *(0,0000)$ & $1,48 * * * *(0,0000)$ \\
\hline Szekszárd/Villány & 1 & $1,03(0,3949)$ & $1,07 *(0,0311)$ & $1,33 * * * *(0,0000)$ & $1,52 * * * *(0,0000)$ \\
\hline Hódmezővásárhely & $0,75^{* * * *}(0,0000)$ & $0,78^{* * * *}(0,0000)$ & $0,81 * * * *(0,0000)$ & 1 & $1,15^{*}(0,0000)$ \\
\hline
\end{tabular}

Zárójelben a statisztikai p-érték, oszlopok a halálozás növekvő sorrendjében. ${ }^{*} \mathrm{p}<0,05 ;{ }^{*} \mathrm{p}<0,01 ;{ }^{* * *} \mathrm{p}<0,001 ;{ }^{* * * *} \mathrm{p}<0,00005$

Villány (3907) vidéken volt, míg a legnagyobb Tokajban (5955). A Balaton (4034) és Eger (4191) viszonylag alacsonyabb és Vásárhely (5178) viszonylag magasabb értékei a két szélső érték közé kerültek. Az országos érték: 4800, ehhez viszonyítva Szekszárd/Villány (3907) és Tokaj (5955) értékei jelentős, ellentétes irányú, szélső eltéréseket mutatnak. Ezeket az adatokat a 2. táblázat mutatja be. Fontos megjegyezni, hogy ezek a tendenciák minden évben hasonló módon, ismétlődően fordultak elő az egyes régiókban.

\section{A gastrointestinalis és a szip-ér rendszeri betegségek relatín kockázata a különböző régiókban, növekvő sorrendben}

A 3/A és 3/B táblázat növekvő sorrendben mutatja be a GI-daganatok és SZÉM-halálozások statisztikailag kiszámolt relatív kockázatát az egyes területeken a vizsgált lakosságszámra vonatkozóan. A GI-daganatok esetében a Tokaj vidék szignifikánsan kisebb kockázati értéket mutat minden más területhez viszonyítva, különösen Szekszárd-Villány és Eger adataihoz képest.
Ezzel szemben a SZÉM mortalitásában a Szekszárd/ Villány vidéken a legkisebb a kockázat, míg Tokajban a legnagyobb. A Balaton és Hódmezővásárhely adatai a két szélső érték közé esnek. Ezekből az eredményekből a következő megállapítások vonhatók le:

- statisztikailag erősen szignifikáns különbségek vannak az egyes területek halálozási értékeiben;

- Tokaj és Szekszárd/Villány-Eger vidékek GI- és SZÉM-adatai egymással ellentétes (reciprok jellegü) tendenciát mutatnak;

- ezekben a különbségekben nem lehet figyelmen kívül hagyni az egyes területekre dominánsan jellemző bortípusok (Tokaj: „fehérbor” és Szekszárd/Villány-Eger „vörösbor”) fogyasztásának egymástól markánsan eltérő hatásait.

\section{A talajminták ásványianyag-tartalma az egyes terïleteken}

A vizsgált területek talajmintáira jellemző, biológiai szempontból legfontosabb ásványi elemek előfordulásának adatait a 4. táblázat tartalmazza a koncentrációk 
4. táblázat |A talaj ásványianyag-tartalma vidékenként 2005-2010 között

\begin{tabular}{lrrrrr}
\hline $\begin{array}{l}\text { Elem } \\
(\mathrm{mg} / \mathrm{kg})\end{array}$ & \multicolumn{1}{l}{ Tokaj } & \multicolumn{1}{l}{ Eger } & Balaton & $\begin{array}{l}\text { Szekszárd/ } \\
\text { Villány }\end{array}$ & $\begin{array}{l}\text { Hódmezó- } \\
\text { vásárhely }\end{array}$ \\
\hline $\mathrm{Ca}$ & 5600,0 & 4715,0 & 45610,0 & 27808,7 & 12100,0 \\
$\mathrm{Fe}$ & 23366,0 & 22500,0 & 14135,0 & 19584,2 & 24500,0 \\
$\mathrm{Mg}$ & 4830,0 & 4212,0 & 7237,0 & 10274,9 & 8557,0 \\
$\mathrm{~K}$ & 2833,0 & 2170,0 & 3845,0 & 1206,0 & 3228,0 \\
$\mathrm{Na}$ & 233,0 & 89,0 & 144,0 & 173,0 & 875,0 \\
$\mathrm{P}$ & 367,0 & 314,0 & 372,0 & 645,9 & 672,0 \\
$\mathrm{~S}$ & 197,0 & 135,0 & 198,0 & 149,2 & 296,0 \\
$\mathrm{Zn}$ & 58,0 & 50,0 & 66,0 & 47,0 & 66,0 \\
$\mathrm{Mo}$ & 1,4 & 1,0 & 1,2 & 0,1 & 0,9 \\
$\mathrm{Se}$ & 1,0 & 1,0 & 1,0 & 0,4 & 1,0 \\
\hline
\end{tabular}

csökkenő sorrendjében. A legnagyobb eltéréseket a P-, $\mathrm{Ca}-, \mathrm{K}-, \mathrm{Mg}_{-}, \mathrm{Na}-$ és Fe-értékek mutatják. Ezek a különbségek azonban nem tükrözik a mortalitási adatok tendenciáit.

\section{Az ivóvizminták ásványianyag-tartalma az egyes területeken}

Az egyes területek vezetékesivóvíz-mintáira jellemző, biológiai szempontból legfontosabb ásványi elemek adatait a 5. táblázat tartalmazza. Figyelemre méltó, hogy Tokaj vidéken a GI-daganatokkal szemben védőhatású szeléntartalom [12] a kétszerese annak, ami a további négy területen, bár ez a különbség a talajértékekben nem látszik. Továbbá itt a talajmintáknál vizsgált elemek mellett bemutatásra kerülnek még a daganatkeltő króm [13] adatai is, kiegészítve a mangán-, arzén-, klorid-, szulfát-, ortofoszfát-koncentrációt és vízkeménységet jellemző számokkal.

\section{Megbeszélés}

E vizsgálatok újnak és meglepőnek számító, statisztikailag erősen szignifikáns eredménye az, hogy Tokaj vidék városaiban 2000-2010 között elhalálozott személyek halálokait összehasonlítva az egri, balatoni, szekszárdi/ villányi borvidékek és Hódmezővásárhely lakosaival, itt volt szignifikánsan a legkisebb a GI-daganatok mortalitásértéke, míg a legnagyobb a SZÉM-eredetû́ elhalálozás. A Szekszárd/Villány-Eger vidékeken ezeknek a fordítottja volt szignifikánsan gyakori. Ezek a különbségek a két országos, mortalitási értékhez viszonyítva jelentős szélsőségként jelennek meg az adott területre jellemző sajátságként. Ez a borvidékekre jellemző tendencia a nem borvidéknek számító, kontrollként szereplő Hódmezővásárhely adataihoz képest is mind a 11 vizsgált évben ismétlődött, és így nem tekinthető „vizsgálati véletlennek". Mi lehet ennek a borvidékfüggő, reciprok jelenségnek az oka és magyarázata? Kezdjük a legéletszerübbekkel!

Az életszínvonal, a DI-érték az országos átlagnál jobb (negatív előjelű) volt mindenütt, bár Tokaj vidék városaiban, ha nagyon kis értékkel is, de a szám abszolút értékben itt volt a legkisebb, jelezve a leggyengébb szociálisgazdasági státuszt. Ezért nem zárható ki, hogy a SZÉM gyakoribb előfordulásában a kicsit rosszabb életkörülmények játszhattak valami szerepet, ami egyébként a hódmezővásárhelyi adatokban is meglátszik, bár itt a daganatok előfordulása is a második legnagyobb értéket

5. táblázat | A vezetékes ivóvíz ásványianyag-tartalma vidékenként 2005-2010 között

\begin{tabular}{|c|c|c|c|c|c|c|}
\hline Elem/vegyület & Mértékegység & Tokaj & Eger & Balaton & Szekszárd/Villány & Hódmezóvásárhely \\
\hline Nátrium & $\mathrm{mg} / \mathrm{l}$ & 25,50 & 13,40 & 13,50 & 107,10 & 88,50 \\
\hline Kálium & $\mathrm{mg} / 1$ & 93,00 & 3,00 & 6,40 & 6,50 & 1,00 \\
\hline Magnézium & $\mathrm{mg} / \mathrm{l}$ & 24,50 & 26,80 & 46,20 & 39,70 & 14,50 \\
\hline Kalcium & $\mathrm{mg} / \mathrm{l}$ & 2,40 & 86,20 & 115,40 & 8,20 & 27,60 \\
\hline Összes keménység & $\mathrm{CaO} \mathrm{mg} / \mathrm{l}$ & 138,60 & 194,90 & 249,20 & 294,20 & 81,90 \\
\hline Foszfát & $\mathrm{mg} / \mathrm{l}$ & 0,10 & 3,10 & n.a. & 17,30 & n.a. \\
\hline Ortofoszfát & $\mathrm{mg} / \mathrm{l}$ & 0,24 & n.a. & n.a. & 2,13 & n.a. \\
\hline Klorid & $\mathrm{mg} / \mathrm{l}$ & 29,50 & 15,90 & 14,20 & 95,50 & 9,30 \\
\hline Szulfát & $\mathrm{mg} / \mathrm{l}$ & 66,50 & 60,40 & 59,00 & 99,10 & 12,70 \\
\hline Mangán & $\mu \mathrm{g} / 1$ & 27,30 & 7,90 & 14,50 & 24,90 & 35,20 \\
\hline Szelén & $\mu \mathrm{g} / 1$ & 1,40 & 0,70 & 0,70 & 0,80 & 0,70 \\
\hline Vas & $\mu g / 1$ & 33,70 & 12,80 & 38,00 & 41,40 & 178,00 \\
\hline Arzén & $\mu g / 1$ & 6,00 & 1,60 & 0,30 & 1,10 & 19,50 \\
\hline Króm & $\mu \mathrm{g} / 1$ & 0,00 & 0,00 & 0,00 & 2,50 & 0,00 \\
\hline
\end{tabular}

n.a. = nincs adat 
mutatja az egyes területek között. Így a DI önmagában nem magyarázza az alacsony GI-mortalitást Tokajban.

A tôkehús típusú (füstölt hús nélküli) sertés- és marhahúsfogyasztás szempontjából a borvidékek szinte azonos értékeket mutattak. Vásárhely kissé kiugró adatai nem magyarázzák a területek közötti mortalitásbeli különbségeket. Meg kell jegyezni azonban, hogy a vöröshús-fogyasztás és a béldaganatok pozitív összefüggését az évi $72 \mathrm{~kg}$ /fő vörös hús (tőkehús + füstölt hús) kvótájú Amerikai Egyesült Államokban találták [6], ahol a teljes húsfogyasztás $125 \mathrm{~kg} /$ fó/év volt 2007-ben [13]. Míg ezek a számok nálunk ebben az évben a következóképpen alakultak: vörös hús (tőkehús + füstölt hús): $29,9 \mathrm{~kg} /$ fő/év és teljes húsfogyasztás: $63,2 \mathrm{~kg} /$ fö/év [14]. Ezekből az adatokból kivehető, hogy az általunk vizsgált területek még hazai viszonylatban sem tartoztak, tartoznak a legnagyobb húsfogyasztók közé, így a meglévő, kis különbségeik egymáshoz viszonyítva elhanyagolhatóak, és nem magyarázzák a mortalitási eltéréseket. Az Amerikai Egyesült Államokban tett, fontos megfigyelések pedig itt nem érvényesek a mintegy fele nagyságú húsfogyasztási mennyiségek miatt.

A talajminták ásványianyag-tartalma alapján jól elkülöníthetők a kalciumban gazdagabb (Balaton, Szekszárd/ Villány) és szegényebb régiók (Tokaj, Eger), mutatva a jelentős eltéréseket az ország különböző pontjain. Feltűnő, hogy a nagy reciprok (inverz), fordított jellegú halálozási különbségeket mutató Tokaj és Eger talaja szinte minden elem vonatkozásában nagyon hasonló, így a „talaj” tényező nem tükrözi a halálozási különbségeket. A magas foszfáttartalom hátterében a fokozott mútrágyahasználat állhat az adott területen [15].

A vezetékes ivóvíz ásványi elemeinek területi megoszlásaiban is nagy különbségek mutatkoznak. Ugyanakkor a vizsgált anyagok körét itt bővítettük néhány nyomelemmel (As, Mn, Cr) és vegyülettel. Meg kell jegyezni, hogy a foszfát és ortofoszfát vonatkozásában a NÉBIH-nek nem állt rendelkezésére adat néhány területen a vizsgált időszakra vonatkozóan. Két szám emelhető ki. Feltûnő, hogy a szeléntartalom a Tokaj vidéken volt a legmagasabb (bár ez a tendencia nem látszott a talajmintákban). Nem lehet figyelmen kívül hagyni, hogy a felszívódott szelénnek lehet védőhatása a tumorokkal szemben [12]. Bár a teljesen azonosan alacsony értéket mutató három vidéken (Eger, Balaton, Hódmezővásárhely) voltak némi különbségek a GI-halálozásban, nevezetesen Egerben kissé magasabb volt ez, mint a két másikban, jelezvén, hogy a szelénen kívül más tényezók hatásaira is szükséges gondolni. Külön eset a króm. Egyedül Szekszárdon lehetett hat mérési pontból két helyen kis koncentrációt kimutatni. A megadott számadat a mérések átlaga. Ugyanakkor figyelembe kell venni a Tolna megyéből korábban történt jelzést, hogy van egy Sióparti hely, ahol jelentős környezeti krómszennyezés mutatható ki, aminek hatása lehet a tumorok ottani gyakoribb előfordulására [16]. Ez a hely Szekszárdtól 59 $\mathrm{km}$ távolságra van, így a kockázat 15 folyókilométeren- ként történő, távolságtól függő fokozatos csökkenésével számolva - amit ez a cikk is kiemel - kizárható, hogy a szekszárdi, magas GI-daganatos halálozásban esetlegesen a Sió-eredetú ivóvíz bár alacsony, de mérhető krómtartalma lenne az ok. Nem felejthető, hogy Egerben krómmentes ivóvíz mellett is magas ez az érték.

A DI, a sertés-marha hús fogyasztása, talaj- és ivóvízadatok különbségei tehát nem tükrözik pontosan a mortalitási adatokban látszó területi különbségeket. Ugyanakkor a dominánsan vörösbortermelő és -fogyasztó Szekszárd/Villány területén és Egerben is megmutatkozik ennek a bornak ismert védőhatása a SZÉM-eredetű elhalálozásokban $[3,4]$. Mind a daganatok, mind a SZÉM előfordulásában azonban a Tokaj terület olyan mértékű különbségeket mutat, amelyben nem zárható ki ennek a vidéknek világviszonylatban is sajátos, különösen az aszúban érvényre jutó borkultúrájának a hatása $[17,18]$.

Meg kell jegyezni, hogy ezek az adatok szigorúan csak a vizsgált, XXI. század kezdeti/körüli időszakra és egy sajátos, adott korosztályra értelmezhetőek Magyarországon. Azóta már változhattak és biztosan jelentősen meg is változtak az életkörülmények ezeken a területeken is. Ez a 11 év, ez az időszak azonban több szempontból nagyon szerencsés periódusnak tartható a „borhatások” közegészségtani vizsgálata szempontjából. Az elhalálozott személyek többsége ugyanis ahhoz a generációhoz tartozott, akik 1935-1948 között születtek, és akik bár életük végén már sokan (kis)városban éltek, de még egy nagy gazdasági válság előtt; továbbá ők még ezer szállal, több évtizeden át kötődhettek az akkor döntő mértékben kis parcellás, bortermelő, falusi családjaikhoz, vagy a saját hétvégi telkeikhez, pincéikhez a hetvenes évektől erősödő, „gulyásfőző és saját bort fogyasztó” társadalmi szokásrendszerben. Ez mára már szinte teljesen megszűnt. Kétségtelen, hogy ekkortól megnőtt a sörfogyasztás is. Figyelemre méltó azonban, hogy a hetvenes években épült bőcsi sörgyártól azonos távolságra fekvő Tokaj és Eger halálozási adataiban markánsan érvényesül a GIés SZÉM-adatok reciprok jellege. Így a „sörhatást” ekkor még el lehet hanyagolni a mortalitási különbségek magyarázatában. Ugyanakkor valószínú, hogy az egy fơre jutó, éves, nettó alkoholra számított „szeszfogyasztásban" nem volt és azóta sincs jelentős különbség ezeken a területeken. Ugyanis a négy borvidéken az alkoholos májzsugorodás egyformán az átlagos rátájú, míg a nem borvidék Vásárhelyen a legalacsonyabb rátájú megyékhez történő besorolást jelentette 1994-ben [19].

Onkológiai szempontból ezen adatok további elemzése szükséges $[20,21]$, hiszen a GI-daganatok csoportja igen sok és egymástól jelentősen eltérő malignitási potenciállal rendelkező betegséget tartalmaz. Nem hagyható figyelmen kívül az sem, hogy a vizsgált 11 éves időperióduson belül igen jelentős változások történtek a metasztatikus daganatok szisztémás és lokális kezelésének lehetőségeiben és algoritmusaiban egyaránt, amelyek érdemben befolyásolták a betegek túlélési esélyeit. 
Ezentúl a mortalitás statisztikai eredményeiben jelentős szerepet kap a terápiához való hozzáférés lehetősége, ami az egyes területeken más és más lehet. Ezen szempontok kooptálása a vizsgálati modellünkbe folyamatban van, továbbá az elemzés kiterjesztése a további, főbb daganatcsoportok irányába is. A vizsgálatokból levonható következtetések:

- Az erősen szignifikáns különbségek értelmezésekor nem lehet eltekinteni az adott vidék domináns bortípusának fogyasztásától, annak hatásaitól.

- A Tokaj és Szekszárd/Villány-Eger vidékeken a GIdaganatos és SZÉM-eredetű mortalitás egymásnak fordított, „reciprok” jelleget mutat.

- Igazolódott a vörösbor védőhatása a szív-ér eredetú elhalálozásokban.

Nyitott kérdések:

- Mi az oka a vörösborfogyasztás és GI-daganat-eredetú mortalitás pozitív összefüggésének?

- Mi az oka a tokajibor-fogyasztás és a GI-daganat-eredetű elhalálozás negatív összefüggésének?

- Mi az oka a tokajibor-fogyasztás és SZÉM-eredetú mortalitás pozitív összefüggésének?

- Lehet-e szerepe ezekben a jelenségekben az „antioxidánsoknak [22]?

Ezekre a kérdésekre keressük a választ jelenleg és a jövőben.

Anyagi támogatás: A kézirat elkészítése és a kapcsolódó munka anyagi támogatásban nem részesült.

Szerzői munkamegosztás: S. S., H. Zs., N. J., K. J.: Hipotézisek kidolgozása. N. J., S. S., K. J., H. Zs.: A vizsgálat lefolytatása. N. J.: Statisztikai elemzések. S. S., H. Zs., N. J., K. J.: A kézirat megszövegezése. A cikk végleges változatát valamennyi szerző elolvasta és jóváhagyta.

Érdekeltségek: A szerzőknek nincsenek érdekeltségeik.

\section{Irodalom}

[1] WHO Regional Office for Europe. European mortality database (MDB). Updated: July 2016. Available from: data.euro.who. int/hfamdb

[2] Kásler M, Ottó Sz, Kenessey, I. The current situation of cancer morbidity and mortality in the light of the National Cancer Registry, Hungary. [A rákmorbiditás és -mortalitás jelenlegi helyzete a Nemzeti Rákregiszter tükrében.] Orv Hetil. 2017; 158: 8489. [Hungarian]

[3] Fehér J, Lengyel G, Lugasi A. Cultural history of wine, the theoretical background of wine therapy. [A bor kultúrtörténete, a borterápia elméleti háttere.] Orv Hetil. 2005, 146: 2635-2639. [Hungarian]

[4] Hernandez-Hernandez A, Gea A, Ruiz-Canela M, et al. Medi terranean alcohol-drinking pattern and the incidence of cardiovascular disease and cardiovascular mortality: the SUN project. Nutrients 2015; 7: 9116-9126.

[5] Daniel S, Bereczki D. Alcohol as a risk factor for hemorrhagic stroke. [Az alkoholfogyasztás és az agyvérzés kockázata.] Clin Neurosci/Ideggy Szle. 2004; 57: 247-256. [Hungarian]
[6] Jeyakumar A, Dissabandara L, Gopalan V. A critical overview on the biological and molecular features of red and processed meat in colorectal carcinogenesis. J Gastroenterol. 2017; 52: 407418.

[7] Waterhouse JA, Muir CS, Correra P, et al. Cancer incidence in five continents, volume 3. IARC Scientific Publications, Lyon, 1976; p. 456.

[8] Széles G, Vokó Z, Jenei T, et al. A preliminary evaluation of health monitoring programme in Hungary. Eur J Public Health $2005 ; 15: 26-32$.

[9] Sándor J, Szerencse P, Szúcs P, et al. Investigation on the local accumulation of tumors derived from environmental factors. [Környezeti eredetû daganatos megbetegedések területi halmozódásának vizsgálata.] Magy Onkol. 2003; 47: 177-183. [Hungarian]

[10] BNO-10: International statistical classification of the problems related to health and diseases. (Revision No. 10.) [BNO-10: A betegségek és az egészséggel kapcsolatos problémák nemzetközi statisztikai osztályozása (10. revízió).] Budapest, Népjóléti Minisztérium (1995). ISBN 9637025413 [Hungarian]

[11] Juhász A, Nagy Cs, Páldy A. Hungarian deprivation index - Development of deprivation index applicable in epidemiological studies. Rapid Inquiry Facility (RIF), Workshop, 2008 March 26-28, Budapest, Workshop Report

[12] Hughes DJ, Fedirko V, Jenab M, et al. Selenium status is associated with colorectal cancer risk in the European prospective investigation of cancer and nutrition cohort. Int J Cancer 2015; 136: 1149-1161.

[13] Horn P. Some questions related to the rational consumption of the natural nutritional resources of Earth. [A Föld természetes tápanyagforrásainak ésszerű hasznosításával összefüggő néhány kérdés.] Magyar Tudomány. 2012; 173: 931-943. [Hungarian]

[14] Agrárgazdasági Kutató Intézet (AKI) 2014, https://sertésinfo. aki.gov.hu/publikációk/ [Hungarian]

[15] Kalocsai R, Giczi Zs, Schmidt R, et al. Interpretation of the results of soil analysis. [A talajvizsgálati eredmények értelmezése.] Available from: http://www.uis.hu/download/A\%20talajvizsgálati\%20eredmenyek\%20ertelmezese.pdf [Hungarian]

[16] IARC Monographs, Volume 49: Chromium, nickel and welding. IARC Scientific Publications, Lyon, 1990.

[17] Magyar I. Botrytized wines. Adv Food Nutr Res. 2011; 63: 147206.

[18] Kiss L. "The tempting kindness of wine." Chapters from the medical curiosites of history of wine civilization. [ „A bornak csábító kedvessége..." Fejezetek a borfogyasztás kultúrtörténetének orvosi kuriózumaiból.] Lege Artis Med. 2009; 19: 720722. [Hungarian]

[19] Elekes Zs, Paksi B. Drinking customs of the Hungarian population. [A magyar lakosság italfogyasztási szokásai.] 1994. Available from: http://nfsz.munka.hu/resource. aspx [Hungarian]

[20] Ma SH, Jung W, Weiderpass E, et al. Impact of alcohol drinking on gastric cancer development according to Helicobacter pylori infection status. Br J Cancer 2015; 113: 1381-1388.

[21] Jayasekara H, Maclnnis RJ, Room R, et al. Long-term consumption and breast, upper aero-digestive tract and colorectal cancer risk: a systemic review and meta-analysis. Alcohol Alcohol. 2016; 51: 315-330.

[22] Gutteridge JM, Halliwell B. Antioxidants, medicines, and mysths. BBRC 2010; 393: 561-564.

(Sipka Sándor dr., Debrecen, Nagyerdei krt. 98., 4032 e-mail: sipka@iiibel.dote.hu) 